\title{
PENGARUH KUALITAS PELAYANAN, DESAIN PRODUK DAN LOKASI TERHADAP KEPUTUSAN PEMBELIAN SONGKET SILUNGKANG ANDE DARAMA DI GUNUNG PANGILUN KOTA PADANG (PLAZA MABEL CENTRAL JEPARA)
}

\author{
Findo Winarto, Maria Magdalena \\ STIE KBP Padang \\ findowinarto@gmail.com
}

\begin{abstract}
Silungkang songket fabric is a custom fabric for the Minang people and is used as a symbol of a person's social status in addition to wealth, consumer purchasing decisions are an intense behavior related to the consumer's desire to behave in a certain way in order to own and use the product. The purpose of this study was to determine the effect of service quality, product design and location on the decision to purchase Songket Silungkang Ande Darama at Padang City Pangilun Mountain (Mabel Central Jepara Plaza). This type of research is quantitative. The population of this study were consumers who came to Ande Darama shop in Padang City Pangilun Mountain (Plaza Jepara Central Furniture) who had felt the service and design of silungkang songket products, which the authors took as many as 312 respondents in 2017 with 75 people taken by simple random sampling. Data is processed using multiple linear regression. The results showed that there was an effect of service quality on consumer purchasing decisions in buying Silungkang songket $t-2.913>$ t table 1.666 , and sig value $0.005<0.05$, there was a product design effect on consumer purchasing decisions in buying songket Silungkangt count 2.995, > t table 1,666, and sig value $0.004<0.05$ and there is a location effect on consumer purchasing decisions in buying Silungkang songket $t$ count 5.847,> t table 1.666, and sig $0.000<0.05$ and suggestions for future researchers to be able to use research as a reference which will later provide comparison in conducting further research.
\end{abstract}

Keywords: Service Quality, Product Design, Location, Purchase Decision

\section{PENDAHULUAN}

Kain songket Silungkang merupakan kain adat bagi masyarakat Minang dan digunakan sebagai simbol status sosial seseorang dalam masyarakatnya selain harta kekayaan.Motif-motif dalam kain songket Silungkang mengandung makna simbolis yang bersifat sakral karena dahulu kain songket dipakai dalam upacara perkawinan, keagamaan dan upacara adat lainnya dan tidak untuk dipakai sehari-hari.Sekarang ini banyak kain songket buatan pabrik yang beredar dipasaran dengan harga relatif terjangkau membuat kain songket buatan tangan menjadi berkurang peminatnya.
Berdasarkan latar belakang tersebut maka timbul permasalahan, yaitu apakah desain produk yang terkandung dalam kain songket Silungkang masih menunjukan makna simbolisnya dan apakah kain songket Silungkang masih digunakan sebagai penentu simbol status sosial seseorang di Budaya Minang,Sumatera Barat.

Karena itu, songket Minang di samping memiliki nilai estetis, juga memiliki makna simbolik. Apakah motif yang terkandung dalam kain songket Silungkang masih menunjukan makna simbolisnya dan 
apakah kain songket Silungkang masih digunakan sebagai penentu simbol status sosial seseorang di Sumatera Barat Kota Padang.

Keputusan pembelian konsumen adalah merupakan intense perilaku yang berkaitan dengan keinginan konsumen untuk berperilaku menurut cara tertentu guna memiliki dan menggunakan produk, keputusan pembelian konsumen menjadi suatu hal yang penting untuk diperhatikan karena hal ini tentu akan menjadi suatu pertimbangan bagaimana suatu strategi pemasaran yang akan dilakukan oleh perusahaan berikutnya (Avetoe \& Lamidi, 2005)

Kualitas pelayanan adalah suatu kondisi dinamis yang berhubungan dengan produk, jasa, manusia, proses danl ingkungan yang memenuhi atau melebihi harapan. Pelayanan adalah setiap tindakan yang dapat ditawarkan oleh suatu pihak kepada pihak lain, yang pada dasarnya tidak berwujud atau tidak mengakibatkan kepemilikan apapun. Layanan purna jual adalah berbagai macam layanan yang disediakan produsen atau perusahaan setelah produk dibeli oleh konsumen.(Mahmud \& Alfianto, 2014)

Kotler \& Keller

mengemukakan bahwa desain produk adalah totalitas fitur yang mempengaruhi penampilan dan fungsi suatu produk tertentu menurut yang diisyaratkan dari segi kebutuhan pelanggan. Sementara itu, Hayes menyatakan bahwa desain produk merupakan factor yang akan sering memberikan kepada perusahaan sisi bersaingnya (Mahmud \& Alfianto, 2014)

Lokasi disebut strategis bila berada dipusat kota, kepadatan populasi, kemudahan mencapainya menyangkut kemudahan transportasi umum, kelancaran lalu lintas dan arahnya tidak membingungkan konsumen(Wibowo, 2014). Hasil penelitian terdahulu yang dilakukan oleh (Avetoe \& Lamidi, 2005) tentang Pengaruh Kualitas Layanan, Ekuitas Merek dan Promosi Terhadap Keputusan Pembelian Produk Lion Star Di Modern Market Jakarta. Hasil penelitian menunjukkan bahwa kualitas pelayanan berpengaruh positif terhadap keputusan pembelian.

Berikut data Penjualan Songket Silungkang Ande Darama di Gunung Pangilun Kota Padang. (Plaza Mebel Sentral Jepara) Januari sampai Juni 2016 pada Tabel 1dibawah ini:

Tabel 1

Data Penjualan Songket Silungkang Ande Darama di Gunung Pangilun Kota Padang dari Bulan Januari Juni 2017

\begin{tabular}{|c|c|c|c|}
\hline No & Bulan & $\begin{array}{c}\text { Penjualan } \\
\text { (Unit) }\end{array}$ & Persen \\
\hline 1 & Januari & 39 & - \\
\hline 2 & Februari & 42 & $7,6 \%$ \\
\hline 3 & Maret & 40 & $4,7 \%$ \\
\hline 4 & April & 38 & $5 \%$ \\
\hline 5 & Mei & 41 & $7,8 \%$ \\
\hline 6 & Juni & 45 & $9,7 \%$ \\
\hline
\end{tabular}

Dari hasil data diatas bisa kita lihat penjualan toko songket silungkang ande darama pada bulan Januari ke Februari mengalami peningkatan sebesar $7,6 \%$ pada bulan Februari ke Maret mengalami penurunan sebesar 4,7 \% sedangkan pada bulan Maret ke April mengalami penurunan kembali sebesar 5\%, Pada bulan April ke Mei mengalami peningkatan sebesar 7,8\% dan pada bulan Mei hingga Juni mengalami peningkatan yang signifikan sebesar $9,7 \%$.

Berdasarkan latar belakang di atas dan bentuk tabel yang tidak stabil dari bulan ke bulan hal inilah yang menjadi alasanpenulis untuk melakukan penelitian tentang. "Pengaruh Kualitas Pelayanan, Desain Produk dan Lokasi Terhadap Keputusan Pembelian Songket Silungkang Ande Darama 
di Gunung Pangilun Kota Padang (Plaza Mabel Central Jepara).

\section{LANDASAN TEORI}

\section{Keputusan Pembelian}

Menurut Kotler \& Keller ( 2012) menyatakan bahwa, "Purchase decision is the buyer's decision about which brand to purchase" yang artinya bahwa keputusan pembelian adalah tahap proses keputusan dimana konsumen secara actual melakukan pembelian produk. Konsumen sebagai pelaku utama dalam proses pembelian selalu menjadi perhatian produsen. Keputusan pembelian yang dilakukan oleh konsumen dapat terjadi apabila kosumen sudah mendapatkan layanan dari pemberian jasa dan setelah itu konsumen merasakan adanya kepuasan dan ketidakpuasan, maka dari itu konsep-konsep keputusan pembelian tidak lepas dari konsep kepuasan konsumen.

\section{Kualitas Pelayanan}

Menurut Sriyanto \& Kuncoro (2015) kualitas layanan merupakan tingkat keunggulan (excellence) yang diharapkan dan pengendalian atas keunggulan tersebut untuk memenuhi keinginan pelanggan. Ada dua faktor utama yang mempengaruhi kualitas layanan perusahaan yaitu harapan pelanggan (expectation) dan kinerja perusahaan yang dirasakan konsumen (performance). Kualitas layanan jasa perusahaan dianggap baik dan memuaskan jika jasa perusahaan yang diterima melampaui harapan konsumen, jika jasa perusahaan yang diterima lebih rendah dari pada yang diharapkan maka kualitas layanan jasa perusahaan dipersepsikan buruk.

\section{Desain Produk}

Kotler \& Keller

mendefinisikan "Design is the totality of features that affect how a product looks, feels, and functions to a consumer.". Hal itu berarti bahwa desain merupakan totalitas fitur yang mempengaruhi bagaimana sebuah produk terlihat, terasa, dan berfungsi bagi konsumen. Desain menawarkan tiga hal:

1. Fungsi
2. Estetika

3. Daya Tarik

Lebih lanjut masih menurut Kotler dan Keller, desain yang baik bagi perusahan adalah kemudahan dalam pembuatan dan distribusi. Sedangkan bagi konsumen, desain yang baik adalah produk yang indah atau bagus untuk dilihat, mudah di buka, dipasang, digunakan, diperbaiki, dan dibuang.

\section{Lokasi}

Menurut Wibowo (2014) Suatu lokasi disebut strategis bila berada dipusat kota, kepadatan populasi, kemudahan mencapainya menyangkut kemudahan transportasi umum, kelancaran lalu lintas dan arahnya tidak membingungkan konsumen. Sejalan dengan semakin menjamurnya bisnis atau usaha yang menawarkan produk atau jasa yang sejenis, perbedaan yang sangat tipis sekalipun pada lokasi dapat berdampak kuat pada pangsa pasar dan kemampu labaan sebuah usaha. Disamping itu, keputusan pemilihan suatu lokasi juga mencerminkan komitmen jangka panjang perusahaan dalam hal keuangan, karena merubah lokasi yang buruk kadangkala sulit dilakukan dan sangat mahal.

\section{Pengembangan Hipotesis}

\section{Pengaruh Kualitas Pelayanan Terhadap Keputusan pembelian Songket Silungkang Ande Darama di Gunung Pangilun Kota Padang (Plaza Mabel Central Jepara)}

Menurut Isnaini et al (2015) mendefinisikan pelayanan adalah perilaku penjual kepada pembeli dengan memberikan kepuasan kepada konsumen atau pembeli, agar konsumen atau pembeli merasa dihargai dan mendapatkan barang atau jasa yang sesuai dengan keinginannya. 
Pernyataan tersebut juga didukung oleh beberapa penelitian terdahulu Sriyanto \& Kuncoro (2015) tentang Pengaruh Kualitas Layanan, Ekuitas Merek dan Promosi Terhadap Keputusan Pembelian Produk Lion Star Di Modern Market Jakarta. Hasil penelitian menunjukkan bahwa kualitas pelayanan berpengaruh positif terhadap keputusan pembelian.

Dari hasil penelitian di atas pengembangan hipotesis di ketahui bahwa:

H1 : Diduga kualitas pelayanan berpengaruh positif terhadap keputusan pembelian

\section{Pengaruh Desain Produk Terhadap} Keputusan pembelian Songket Silungkang Ande Darama di Gunung Pangilun Kota Padang (Plaza Central Mabel Jepara)

Desain yang baik bagi perusahan merujuk pada kemudahan dalam pembuatan dan distribusi. Sedangkan bagi konsumen, desain yang baik adalah produk yang indah atau bagus untuk dilihat, mudah di buka, dipasang, digunakan, diperbaiki, dan dibuang (Kotler \& Keller, 2012).

Pernyataan tersebut juga didukung oleh Saidani (2013) tentang Pengaruh Kualitas Produk Dan Desain Produk Terhadap Keputusan Pembelian Sepatu Olahraga Futsal Adidas Di Wilayah Jakarta Timur. Hasil penelitian menunjukkan bahwa desain produk berpengaruh positif terhadap keputusan pembelian.

Dari hasil penelitian di atas pengembangan hipotesis di ketahui bahwa:

$\mathrm{H} 2$ : Diduga desain produk berpengaruh positif terhadap keputusan pembelian

3. Pengaruh Lokasi Terhadap Keputusan pembelian Songket Silungkang Ande Darama di Gunung Pangilun (Plaza Mabel Central Jepara)

Suatu lokasi disebut strategis bila berada dipusat kota, kepadatan populasi, kemudahan mencapainya menyangkut kemudahan transportasi umum, kelancaran lalu lintas dan arahnya tidak membingungkan konsumen (Wibowo, 2014)

Penelitian ini dilakukan oleh Avetoe \& Lamidi (2005) Tentang Pengaruh Harga, Kualitas Pelayanan Dan Lokasi Terhadap Keputusan Pembelian Konsumen.

Dari hasil penelitian di atas pengembangan hipotesis di ketahui bahwa:

H3 : Diduga lokasi berpengaruh positif terhadap keputusan pembelian

\section{METODE PENELITIAN}

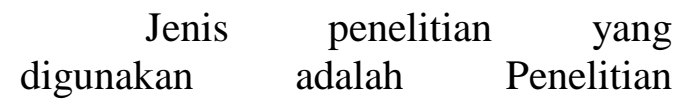

Kuantitatif. Dalam penilitian ini yang menjadi objek penelitian seluruh konsumen yang membeli Songket Silungkang Ande Darama di Gunung Pangilun Kota Padang. (Plaza Mabel Sentral Jepara ). Populasi penelitian ini adalah konsumen yang datang ke toko Ande Darama di Gunung Pangilun Kota Padang (Plaza Mebel Central Jepara) yang telah merasakan pelayanan dan desain produk songket silungkang,yang penulis ambil sebanyak 312 orang Responden pada tahun 2017 dengan Jadi jumlah sampel pada penelitian ini adalah 75 Sampel. Pengambilan sampel dengan menggunakan teknik purposive sampling. Jenis data yang digunakan dalam penelitian ini berupa data kuantitatif. Data Kuantitatif adalah data yang berhubungan dengan kategorisasi, karakteristik berwujud pertanyaan atau berupa kata-kata. Data ini biasanya didapat dari wawancara dan bersifat subjektif. Data kuantitatif dapat berbentuk ordinal atau ranking (Sugiyono, 2015a).

Teknik pengumpulan data dalam penelitian ini adalah Survey, Survey merupakan teknik 
pengumpulan data dimana data diperoleh berdasarkan pemberian kuesioner terhadap sampel yang diteliti.

\section{Definisi Operasional Variabel}

Variabel penelitian dijelaskan sebagai atribut untuk seseorang, atau Objek yang mempunyai variasi antara satu orang dengan yang lain atau satu objek dengan beberapa objek lain (Sugiyono, 2015a).

Variabel yang digunakan dalam penelitian ini adalah variabel bebas (independent variable), variabel terikat (dependent variable).

1. Variabel Bebas (independent variable)

Variabel bebas adalah variabel yang mempengaruhi atau yang menjadi sebab perubahannya atau timbulnya variabel dependen atau terikat (Sugiyono, 2015a). Dalam penelitian ini variabel bebasnya adalah kualitas pelayanan, desain produk, dan lokasi.

2. Variabel Terikat (dependent variable)

Variabel terikat merupakan variabel yang dipengaruhi atau menjadi akibat karena adanya variabel bebas (Sugiyono, 2015a). Variabel terikat dalam penelitian ini adalah keputusan pembelian.

\section{Teknik Analisis Data}

\section{Uji Instrumen Penelitian}

a. Uji Validitas

Pengambilan keputusan adalah:
a. Jika
Corrected
Item-Total
Correlation > 0,300 maka dimensi tersebut valid.
b. Jika Corrected Item-Total Correlation $<0,300$ maka dimensi tersebut tidak valid.

\section{b.Uji Reliabilitas}

Salah satu pengambilan keputusan reliabilitas adalah :

a. Jika Cronbach's Alpha positif, serta Cronbach's Alpha > 0,60 maka dimensi tersebut reliabel.

b. Jika Cronbach's Alpha negatif, serta Cronbach's Alpha $<0,60$ maka dimensi tersebut tidak reliabel.

2. Uji TCR (Tingkat Capaian Responden)
Untuk mencari tingkat keakuratan jawaban responden digunakan rumus berikut:

$$
T C R=\frac{\text { rata }- \text { rata }}{s t_{t}}
$$

Pengkatagorian nilai mencapai responden digunakan klasifikasi (Sugiyono, 2015) sebagai berikut:

Tabel 2

RentangSkala TCR

\begin{tabular}{|c|c|c|}
\hline No & Angka & Keterangan \\
\hline 1 & $81 \%-100 \%$ & Sangat Baik \\
\hline 2 & $61 \%-80 \%$ & Baik \\
\hline 3 & $41 \%-60 \%$ & Netral \\
\hline 4 & $21 \%-40 \%$ & Kurang Baik \\
\hline 5 & $0 \%-20 \%$ & $\begin{array}{c}\text { Sangat Tidak } \\
\text { Baik }\end{array}$ \\
\hline
\end{tabular}

3. Uji Asumsi Klasik

a. Uji Normalitas

Dalam pengujian ini menggunakan indikator uji Kolmogrov-smirnov dengan pedoman sebagai berikut :

a. Jika nilai probabilitas >0,05 maka Ho diterima

b. Jika nilai probabilitas $<0,05$ maka Ho ditolak

b.Uji Multikolinearitas Kriteria pengujian multikolinearitas adalah sebagai berikut:
a. Tolerance $>0.1$
b. Variance Inflation Factor (VIF) $<10$

\section{Uji Liniearitas}

Pengujian pada SPSS dengan menggunakan test of linearity dengan nilai signifikan 0,05 . Jika dua buah variabel dikatakan mempunyai hubungan linearitas bila signifikan lebih dari $0,05, \mathrm{Uji}$ ini apabila nilai signifikan dari kedua variabel yang di uji melalui test of linearity lebih dari 0,05 , maka hubungan kedua variabel mempunyai hubungan linieritas. 
D. Uji Heteroskedastisitas

Model koefisien regresi yang sangat baik adalah yang tidak terjadi gejala heteroskedastisitas. Jika pvalue > 0,05 tidak signifikan berarti tidak terjadi heteroskedastisitas artinya model regresi lolos uji heteroskedastisitas.

Oleh karena itu, apabila jika pvalue > 0,05 , maka tidak terjadi gejala heteroskedastisitas.

C. Uji Autokorelasi

Cara mendeteksi gejala autokorelasi adalah dengan menggunakan menggunakan rumus nilai DW (Durbin Watson). Tingkat signifikan yang ditetapkan adalah $5 \%$. Jika nilai signifikan yang dihasilkan berada $<5 \%$ maka autokorelasi antara data sekarang dengan data sebelumnya, namun jika nilai signifikan yang dihasilkan $>5 \%$ maka tidak ada gejala Autokorelasi.

\section{Analisis Regresi Berganda}

Analisis regresi berganda merupakan untuk mengetahui hubungan antara variabel independen dan variabel dependen.

$\mathrm{Y}=\alpha+\beta 1 \mathrm{X} 1+\beta 2 \mathrm{X} 2+\beta 3 \mathrm{X} 3+\mathrm{e}$

\section{Uji Hipotesis}

\section{T-Test (Uji t statistik)}

Dalam uji statistik t dasarnya adalah untuk mengetahui seberapa baik pengaruh satu variabel independen secara perorangan dalam menjelaskan variabel dependen. Pengujian $t$ statistik didapatkan dengan menggunakan signifikan level $0,05(\alpha=5 \%)$. Apakah hipotesis diterima atau ditolak dilakukan dengan kriteria sebagai berikut:

2. Koefisien determinasi $\left(\mathrm{R}^{2}\right)$

Pengujian koefisien determinasi intinya adalah untuk melihat seberapa jauh kemampuan model dalam menjelaskan variasi variabel dependen. Nilai koefisien determinasi didapatkan antara nol dan satu. Jika niilai $\mathrm{R}^{2}$ yang didapatkan bernilai kecil berarti kemampuan variabel-variabel independen dalam menjelaskan variasi variabel dependen sangat terbatas.

\section{HASIL DAN PEMBAHASAN}

Deskripsi statistik responden menjelaskan mengenai frekuensi dan persentase responden berdasarkan jenis kelamin, umur, pekerjaan, ratarata pendapatan dan pendidikan.

\section{Responden Berdasarkan Jenis} Kelamin

Deskripsi responden berdasarkan jenis kelamin bertujuan untuk menggelompokkan responden berdasarkan jenis kelamin. Proporsi responden berdasarkan jenis kelamin pada penelitian ini dapat dilihat pada tabel berikut ini:

\section{Tabel 3}

\section{Karakteristik Responden}

Berdasarkan Jenis Kelamin

\begin{tabular}{|c|c|c|}
\hline $\begin{array}{c}\text { Jenis } \\
\text { Kelamin }\end{array}$ & $\begin{array}{c}\text { Frekuensi } \\
\text { (Orang) }\end{array}$ & Persentase \\
\hline Laki-Laki & 19 & 25.3 \\
\hline Perempuan & 56 & 74.7 \\
\hline Total & 75 & $100 \%$ \\
\hline \multicolumn{2}{|l}{ Sumber: Hasil Analisis } & Data
\end{tabular}

Penelitian Th.2018

Tabel diatas menjelaskan bahwa komposisi jenis kelamin responden, dimana 56 orang $(74,7 \%)$ responden adalah perempuan dan sebanyak 19 orang $(25,3 \%)$. Jadi dapat disimpulkan jenis kelamin perempuan paling banyak pada penelitian ini.

\section{Responden Berdasarkan Umur}

Deskripsi responden berdasarkan umur bertujuan untuk menggelompokkan responden berdasarkan umur. Proporsi responden berdasarkan umur pada penelitian ini dapat dilihat pada tabel berikut ini: 
Tabel 4

Karakteristik Responden Berdasarkan Umur

\begin{tabular}{|c|c|c|}
\hline Jenis Kelamin & $\begin{array}{c}\text { Frekuensi } \\
\text { (Orang) }\end{array}$ & $\begin{array}{c}\text { Persenta } \\
\text { se }\end{array}$ \\
\hline >45 Tahun & 26 & 34.7 \\
\hline 20-30 Tahun & 6 & 8.0 \\
\hline 31-45 Tahun & 43 & 57.3 \\
\hline Total & 75 & $100 \%$ \\
\hline
\end{tabular}

Sumber: Hasil Analisis Data Penelitian Th.2018

Tabel diatas menjelaskan bahwa komposisi umur responden, dimana 26 orang $(34,7 \%)$ responden dengan umur $>45$ tahun, sebanyak 6 orang (8\%) dan sebanyak 43 orang $(57,3 \%)$ dengan umur 31-45 tahun. Jadi dapat disimpulkan umur responden paling banyak adalah 31-45 tahun.

\section{Responden Berdasarkan Status} Pekerjaan

Deskripsi responden berdasarkan status pekerjaan bertujuan untuk menggelompokkan responden berdasarkan status pekerjaan. Proporsi responden berdasarkan status pekerjaan pada penelitian ini dapat dilihat pada tabel berikut ini:

\section{Tabel 5}

Karakteristik Responden Berdasarkan Status Pekerjaan

\begin{tabular}{|c|c|c|}
\hline $\begin{array}{c}\text { Status } \\
\text { Pekerjaan }\end{array}$ & $\begin{array}{c}\text { Frekuensi } \\
\text { (Orang) }\end{array}$ & $\begin{array}{c}\text { Persentase } \\
(\%)\end{array}$ \\
\hline $\begin{array}{l}\text { Pegawai } \\
\text { Swasta }\end{array}$ & 13 & 17.3 \\
\hline PNS & 37 & 49.3 \\
\hline $\begin{array}{l}\text { Wiraswas } \\
\text { ta }\end{array}$ & 25 & 33.3 \\
\hline Total & 75 & 100 \\
\hline
\end{tabular}
Th. 2018

Tabel diatas menjelaskan bahwa status pekerjaan responden, dimana $17,3 \%$ atau sebanyak 13 orang bekerja sebagai pegawai wiraswasta, $49,3 \%$ atau sebanyak 37 orang bekerja sebagai PNS, $49,3 \%$ atau sebanyak 25 orang bekerja sebagai wiraswasta, 33,3\%. Jadi dapat disimpulkan bahwa responden yang paling banyak yaitu bekerja sebagai PNS yaitu sebanyak 37 orang.

\section{Responden Berdasarkan Rata-Rata} Pendapatan

Deskripsi responden berdasarkan rata-rata pendapatan bertujuan untuk menggelompokkan responden berdasarkan rata-rata pendapatan. Proporsi responden berdasarkan rata-rata pendapatan pada penelitian ini dapat dilihat pada tabel berikut ini:

\section{Tabel 6}

Karakteristik Responden Berdasarkan Rata-Rata Pendapatan

\begin{tabular}{|c|c|c|}
\hline $\begin{array}{c}\text { Rata-Rata } \\
\text { Pendapatan }\end{array}$ & $\begin{array}{c}\text { Frekuensi } \\
\text { (Orang) }\end{array}$ & $\begin{array}{c}\text { Persen } \\
\text { tase } \\
(\%)\end{array}$ \\
\hline$>6$ Juta & 14 & 18.7 \\
\hline $\begin{array}{l}2,5 \text { juta- } 3,5 \\
\text { juta }\end{array}$ & 9 & 12.0 \\
\hline 4 juta-6 juta & 52 & 69.3 \\
\hline Total & 75 & $100 \%$ \\
\hline Sumber: $\quad$ Has & Analisis & Data \\
\hline
\end{tabular}

Penelitian Th.2018

Tabel diatas menjelaskan bahwa rata-rata pendapatan responden, dimana $18,7 \%$ atau sebanyak 14 responden dengan rata-rata pendapatan $>6$ juta, $12 \%$ atau sebanyak 9 orang dengan pendapatan 2,5 juta-3,5 juta, $69,3 \%$ atau sebanyak 52 orang dengan rata-rata pendapatan 4juta-6juta. Jadi dapat disimpulkan bahwa pengunjung yang paling banyak dengan rata-rata pendapatan 4-6 juta sebanyak 52 orang.

\section{Responden Berdasarkan}

Pendidikan Terakhir

Deskripsi responden

berdasarkan pendidikan terakhir bertujuan untuk menggelompokkan responden berdasarkan pendidikan terakhir. Proporsi responden berdasarkan pendidikan terakhir pada penelitian ini dapat dilihat pada tabel berikut ini: 
Tabel 7

Karakteristik Responden Berdasarkan

Pendidikan Terakhir

\begin{tabular}{|l|c|c|}
\hline $\begin{array}{c}\text { Pendidikan } \\
\text { Terakhir }\end{array}$ & $\begin{array}{c}\text { Frekuensi } \\
\text { (Orang) }\end{array}$ & $\begin{array}{c}\text { Persentase } \\
(\boldsymbol{\%})\end{array}$ \\
\hline $\begin{array}{l}\text { Tamat } \\
\text { Kuliah }\end{array}$ & 68 & 90.7 \\
\hline Tamat SMA & 7 & 9.3 \\
\hline Total & 75 & $100 \%$ \\
\hline
\end{tabular}

Sumber: Hasil Analisis Data Penelitian Th. 2018

Tabel diatas menjelaskan bahwa status pendidikan terakhir responden, dimana $90,7 \%$ atau sebanyak 68 responden berpendidikan terakhir tamat kuliah, 9,3\% atau sebanyak 7 orang nasabah berpendidikan terakhir tamat SMA. Jadi dapat disimpulkan bahwa pengunjung yang paling banyak berpendidikan terakhir Perguruan Tinggi yaitu sebanyak 68 orang.

\section{Hasil Analisis Penelitian \\ 1. Uji Asumsi Klasik \\ a. Uji Normalitas}

Uji Normalitas bertujuan untuk menguji apakah dalam suatu model regresi mempunyai distribusi yang normal. Dalam penelitian ini digunakan uji One Sample Kolmogorov-Smirnov. Uji One Sample Kolmogorov-Smirnov dasar keputusannya adalah berdasarkan probabilitas (asymptotic significance), yaitu jika pvalue > 0,05 maka dapat disimpulkan data tersebut bernilai normal.

Tabel 8

Uji Normalitas

One-Sample Kolmogorov-Smirnov Test

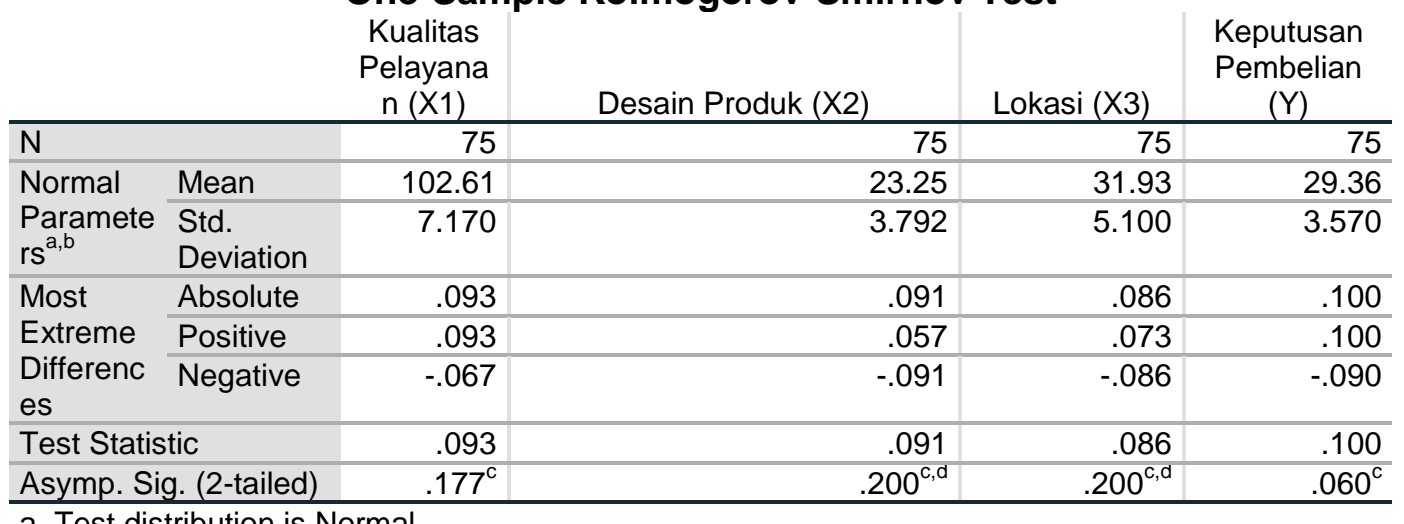

a. Test distribution is Normal.

Sumber: Data Primer diolah dengan SPSS Th.2018

Berdasarkan hasil pengolahan data diatas terlihat bahwa nilai asymp.sig > 0,05 untuk smeua variabel yaitu kualitas pelayanan, desain produk,lokasi dan keputusan pembelian. Maka dapat disimpulkan bahwa hasil uji normalitas kolmogrov-smirnov data tersebut terdistribusi normal karena nilai signifikan lebih besar dari 0,05.

\section{B. Uji Multikolinearitas}

Uji multikolinieritas bertujuan untuk menguji apakah model regresi yang ditemukan adanya korelasi antar variabel bebas. Model regresi yang baik adalah tidak

terjadi gejala multikoliniaritas Error! Reference source not found. Kriteria uji multikolinearitas yaitu apabila Tolerance < 0,10 dan VIF > 10 Maka ada Multikolinearitas.

\section{Tabel 9}

\section{Hasil Uji Multikolinearitas Coefficients $^{a}$}

\begin{tabular}{|c|c|c|c|}
\hline \multirow{2}{*}{\multicolumn{2}{|c|}{ Model }} & \multicolumn{2}{|c|}{$\begin{array}{c}\text { Collinearity } \\
\text { Statistics }\end{array}$} \\
\hline & & Tolerance & VIF \\
\hline \multirow[t]{3}{*}{1} & Kualitas Pelayanan (X1) & .975 & 1.026 \\
\hline & Desain Produk (X2) & .972 & 1.028 \\
\hline & Lokasi (X3) & .960 & 1.042 \\
\hline
\end{tabular}


Sumber: Data Primer diolah dengan SPSS Th. 2018

Berdasarkan hasil pengolahan data diatas pada table 4.25 dapat dilihat bahwa masing-masing variabel independen memiliki nilai tolerance $>0.1$, dan masingmasing variabel independent VIF $<10$ berdasarkan hasil pengolahan data diatas maka dapat disimpulkan bahwa penelitian ini terbebas dari masalah Multikolinearitas.

\section{Uji Linearitas}

Hasil perhitungan uji linearitas variabel kualitas pelayanan, desain produk dan lokasi terhadap variabel keputusan pembelian diolah dengan bantuan program komputer software SPSS versi 24 for windows pada tabel 9

\section{Tabel 10}

Rangkuman Uji Linearitas Variabel X terhadap Variabel Y

\begin{tabular}{|c|c|c|c|}
\hline \multirow{2}{*}{ Variabel } & \multicolumn{3}{|c|}{ Deviation from Linerity } \\
\cline { 2 - 4 } & Df & F & Sig. \\
\hline X1-Y & 27 & 0.827 & 0.696 \\
\hline X2-Y & 14 & 0.931 & 0.532 \\
\hline X3-Y & 18 & 1.536 & 0.113 \\
\hline
\end{tabular}

Sumber: Data Primer diolah dengan SPSS Th.2018
Berdasarkan hasil perhitungan dengan software SPSS versi 24 for window, diperoleh skor $\mathrm{r}$ (probability value) variabel kualitas pelayanan, desain produk dan lokasi nilai signifikansi >0,05. Berdasarkan landasan pengambilan keputusan di atas, Ha diterima dan Ho ditolak sehingga data distribusi kualitas pelayanan, desaij produk dan lokasi dengan keputusan pembelian (Y) berpola linear.

\section{Uji Heteroskedastisitas}

Uji Heteroskedastisitas digunakan menguji apakah dalam model regresi terjadi ketidaksamaan variance dari residual satu pengamatan ke pengamatan yang lain. Penelitian ini menggunakan dua metode uji heteroskedastisitas yaitu dengan model uji glejser. Untuk model uji glejser jika probabilitas > 0,05 berarti tidak terjadi heteroskedastisitas. Metode garis plot apabila plot menyebar dan tidak membentuk suatu pola maka tidak terjadi masalah heteroskedastisitas.

\begin{tabular}{|c|c|c|c|c|c|}
\hline \multirow[b]{3}{*}{ Model } & \multicolumn{3}{|c|}{$\begin{array}{c}\text { Tabel } 11 \\
\text { Hasil Uji Heteroskedastisitas } \\
\text { Coefficients }^{\text {a }}\end{array}$} & \multirow[b]{3}{*}{$\mathrm{t}$} & \multirow[b]{3}{*}{ Sig. } \\
\hline & \multicolumn{2}{|c|}{$\begin{array}{l}\text { Unstandardized } \\
\text { Coefficients }\end{array}$} & \multirow{2}{*}{$\begin{array}{l}\text { Standardized } \\
\text { Coefficients } \\
\text { Beta }\end{array}$} & & \\
\hline & $\mathrm{B}$ & Std. Error & & & \\
\hline $\begin{array}{ll}1 & \text { (Constant) }\end{array}$ & 4.161 & 2.863 & & 1.453 & .151 \\
\hline Kualitas Pelayanan (X1) & -.016 & .026 & -.073 & -.606 & .546 \\
\hline Desain Produk (X2) & -.023 & .049 & -.055 & -.460 & .647 \\
\hline Lokasi (X3) & .000 & .037 & .002 & .014 & .989 \\
\hline
\end{tabular}

a. Dependent Variable: ABRES

Sumber: Data Primer diolah dengan SPSS Th.2018

Berdasarkan hasil uji heteroskedastisitas diatas dapat diketahui bahwa nilai signifikan variabel kualitas pelayanan, desain produk dan lokasi nilai semuanya $>0,05$. Jadi dapat disimpulkan bahwa semua nilai variabel kualitas pelayanan, desain produk dan lokasi terbebas dari gejala heteroskedastisitas.

\section{E. Uji Autokorelasi}

Autokorelasi merupakan korelasi time series (lebih menekankan pada dua data penelitian berupa data rentetan waktu). Cara mendeteksi ada tidaknya gejala autokorelasi adalah dengan menggunakan nilai DW (Durbin Watson) Error! Reference 
source not found.. Tingkat signifikan yang ditetapkan adalah $5 \%$.

Tabel 12

Hasil Uji Autokorelasi

Model Summary ${ }^{\mathrm{b}}$

\begin{tabular}{lll} 
Model & Durbin-Watson & \\
\hline 1 & & $1.990^{\mathrm{a}}$
\end{tabular}

a. Predictors: (Constant), Lokasi (X3), Kualitas

Pelayanan (X1), Desain Produk (X2)

b. Dependent Variable: Keputusan Pembelian (Y)

Sumber: Data Primer diolah dengan SPSS Th. 2018

Berdasarkan hasil pengolahan data diatas pada table 4.27 dapat dilihat bahwa nilai Durbin Watson sebesar 1,990. Nilai 1,990 berada diantara 1,55 - 2,46 berdasarkan hasil pengolahan data diatas maka dapat disimpulkan bahwa penelitian ini terbebas dari masalah Autokorelasi.

\section{Uji Regresi Linear Berganda}

Analisis regresi berganda dalam penelitian ini dilakukan dengan menggunakan bantuan program SPSS Versi 24.0 dapat dilihat pada Tabel dibawah ini :

Tabel 13

Hasil Analisis regresi Berganda Coefficients $^{\mathrm{a}}$

\begin{tabular}{|c|c|c|c|c|c|c|}
\hline \multirow{3}{*}{\multicolumn{2}{|c|}{ Model }} & \multirow{2}{*}{\multicolumn{2}{|c|}{$\begin{array}{l}\text { Unstandardized } \\
\text { Coefficients }\end{array}$}} & \multirow{3}{*}{$\begin{array}{c}\text { Standardized } \\
\text { Coefficients } \\
\text { Beta } \\
\end{array}$} & \multirow[b]{3}{*}{$\mathrm{t}$} & \multirow[b]{3}{*}{ Sig. } \\
\hline & & & & & & \\
\hline & & $\mathrm{B}$ & Std. Error & & & \\
\hline 1 & (Constant) & -.633 & 4.757 & & -.133 & .894 \\
\hline & Kualitas Pelayanan (X1) & .126 & .043 & .252 & 2.913 & .005 \\
\hline & Desain Produk (X2) & .245 & .082 & .260 & 2.995 & .004 \\
\hline & Lokasi (X3) & .357 & .061 & .510 & 5.847 & .000 \\
\hline
\end{tabular}

a. Dependent Variable: Keputusan Pembelian (Y)

Sumber: Data Primer diolah dengan SPSS Th.2018

Berdasarkan hasil yang terdapat pada Tabel 4.29 di atas, maka dapat dirumuskan persamaan regresi linear berganda sebagai berikut:

$\mathrm{Y}=\mathrm{a}+\mathrm{b}_{1} \mathrm{X}_{1}+\mathrm{b} 2 \mathrm{X} 2+\mathrm{b} 3 \mathrm{X} 3$

$Y=-0,633+0,126 X_{1}+0,245 X_{2}+0,357 X_{3}$

1. Dari model persamaan regresi linear berganda di atas dapat diketahui bahwa nilai konstanta sebesar -0,633, yang berarti bahwa tanpa adanya pengaruh dari variable kualitas pelayanan, desain produk dan lokasi maka keputusan pembelian mencapai $-0,633$ satuan.

2. Koefisien regresi variabel kualitas pelayanan $\left(\mathrm{X}_{1}\right)$ sebesar 0,126 . Hal ini berarti apabila kualitas pelayanan meningkat sebesar satu satuan maka keputusan pembelian akan meningkat sebesar 0,126 dalam setiap satuannya. Dengan asumsi variabel lain tidak mengalami perubahan atau konstan.

3. Koefisien regresi variabel desain produk $\left(\mathrm{X}_{2}\right)$ sebesar 0,245. Hal ini berarti apabila desain produk meningkat sebesar satu satuan maka keputusan pembelian akan meningkat sebesar 0,245 dalam setiap satuannya. Dengan asumsi variabel lain tidak mengalami perubahan atau konstan.

4. Koefisien regresi variabel lokasi $\left(\mathrm{X}_{3}\right)$ sebesar 0,357. Hal ini berarti apabila dlokasi meningkat sebesar satu satuan maka keputusan pembelian akan meningkat sebesar 0,357 dalam setiap satuannya. Dengan asumsi variabel lain tidak mengalami perubahan atau konstan.

\section{Uji Hipotesis}

\section{Uji T}

Uji $\mathrm{T}$ dilakukan untuk melihat apakah ada pengaruh yang signifikan atau tidak secara parsial antara kualitas pelayanan, desain produk dan lokasi terhadap keputusan pembelian konsumen. Adapun hasilnya dapat dilihat pada tabel 
Tabel 14

\begin{tabular}{|c|c|c|c|c|c|c|}
\hline & & & $\begin{array}{l}\text { sil Analis } \\
\text { Jefficients }\end{array}$ & Uji T & & \\
\hline & & $\begin{array}{l}\text { Unsta } \\
\text { Coe }\end{array}$ & $\begin{array}{l}\text { lardized } \\
\text { cients }\end{array}$ & $\begin{array}{c}\text { Standardized } \\
\text { Coefficients }\end{array}$ & & \\
\hline & & $\mathrm{B}$ & Std. Error & Beta & $\mathrm{t}$ & Sig. \\
\hline$\overline{1}$ & (Constant) & -.633 & 4.757 & & -.133 & .894 \\
\hline & Kualitas Pelayanan (X1) & .126 & .043 & .252 & 2.913 & .005 \\
\hline & Desain Produk (X2) & .245 & .082 & .260 & 2.995 & .004 \\
\hline & Lokasi (X3) & .357 & .061 & .510 & 5.847 & .000 \\
\hline
\end{tabular}

a. Dependent Variable: Keputusan Pembelian (Y)

Sumber: Data Primer diolah dengan SPSS Th.2018

Berdasarkan hasil pengolahan data diatas pada tabel 4.21 hasil uji t parsial, maka dapat disimpulkan bahwa:

1. Dari tabel diatas terlihat bahwa kualitas pelayanan memiliki nilai koefisien regresi positif dengan nilai $t$ hitung sebesar 2,913 dengan nilai sig sebesar 0,005. Jika dibandingkan dengan (t tabel, sig 0.05, df (75-3) = 72. Maka dapat terlihat bahwa dengan nilai $\mathrm{t}$ hitung 2,913>t tabel 1,666, dan nilai sig $0,005<0.05$, maka dapat disimpulkan bahwa $\mathrm{Ha}$ diterima dan Ho ditolak artinya bahwa kualitas pelayanan berpengaruh dan signifikan terhadap keputusan pembelian.

2. Dari tabel diatas terlihat bahwa desain produk memiliki nilai koefisien regresi positif dengan nilai $t$ hitung sebesar 2,995 dengan nilai sig sebesar 0,004. Jika dibandingkan dengan ( $\mathrm{t}$ tabel, sig 0.05, df (75-3) = 72). Maka dapat terlihat bahwa dengan nilai $\mathrm{t}$ hitung 2,995, $>\mathrm{t}$ tabel 1,666, dan nilai sig $0,004<0.05$, maka dapat disimpulkan bahwa $\mathrm{Ha}$

diterima dan Ho ditolak artinya bahwa desaij produk berpengaruh dan signifikan terhadap keputusan pembelian konsumen.

3. Dari tabel diatas terlihat bahwa lokasi memiliki nilai koefisien regresi positif dengan nilai $\mathrm{t}$ hitung sebesar 5,847 dengan nilai sig sebesar 0,000. Jika dibandingkan dengan (t tabel, sig 0.05, df (75-3) = 72). Maka dapat terlihat bahwa dengan nilai $\mathrm{t}$ hitung $5,847,>\mathrm{t}$ tabel 1,666 , dan nilai sig $0,000<$ 0.05 , maka dapat disimpulkan bahwa $\mathrm{Ha}$ diterima dan $\mathrm{Ho}$ ditolak artinya bahwa lokasi berpengaruh dan signifikan terhadap keputusan pembelian konsumen.

Koefisien Determinasi $\mathbf{R}^{2}$

Koefisien

determinasi

bertujuan untuk mengukur seberapa jauh kemampuan model dalam menerangkan variasi variabel dependen.

\section{Tabel 15}

\section{Hasil Analisis Koefisien Determinasi R2}

Model Summary

\begin{tabular}{lr|rr|r} 
Model & $\mathrm{R}$ & $\mathrm{R}$ Square & Adjusted R Square & Std. Error of the Estimate \\
\hline 1 & $.693^{\mathrm{a}}$ & .481 & .459 & 2.627 \\
\hline
\end{tabular}

a. Predictors: (Constant), Lokasi (X3), Kualitas Pelayanan (X1), Desain Produk (X2)

Sumber: Data Primer diolah dengan SPSS Th.2018

Berdasarkan tabel 4.22 diatas pembelian dipengaruhi oleh kualitas dapat terlihat bahwa besarnya nilai $\mathrm{R}$ Square (dilihat dari Adjusted $\mathrm{R}$ square) sebesar 0,459 . Hal ini berarti $45,9 \%$ keputusan pelayanan, desain produk dan lokasi sedangkan sisanya $44,1 \%$ disebabkan oleh hal-hal lain yang ada diluar 
penelitian seperti kepercayaan, promosi dan lain-lain.

\section{PEMBAHASAN}

Berdasarkan hasil penelitian tentang Pengaruh Kualitas Pelayanan, Desain Produk dan Lokasi Terhadap Keputusan Pembelian Songket Silungkang Ande Darama di Gunung Pangilun Kota Padang ( Plaza Mabel Central Jepara), maka pembahasan dapat diberikan sebagai berikut:

1. Pengujian kualitas pelayanan terhadap keputusan pembelian Songket Silungkang Ande Darama di Gunung Pangilun Kota Padang.

Berdasarkan penelitian diperoleh hasil nilai koefisien regresi positif dengan nilai t hitung sebesar 2,913 dengan nilai sig sebesar 0,005. Jika dibandingkan dengan $(\mathrm{t}$ tabel, sig 0.05, df (75-3) = 72. Maka dapat terlihat bahwa dengan nila i t hitung $-2,913$ $>\mathrm{t}$ tabel 1,666, dan nilai sig 0,005 $<0.05$, maka dapat disimpulkan bahwa Ha diterima dan Ho ditolak artinya bahwa kualitas pelayanan berpengaruh dan signifikan terhadap keputusan pembelian.

Mendukung penelitian sebelumnya yang dilakukan oleh Avetoe \& Lamidi (2005) tentang Pengaruh Harga, Kualitas Pelayanan Dan Lokasi Terhadap Keputusan Pembelian Konsumen Haja Hasil penelitian menunjukkan bahwa kualitas pelayanan berpengaruh positif terhadap keputusan pembelian dan Isnaini et al (2015) tentang Analisis Pengaruh Kualitas Pelayanan, Kualitas Produk Dan Promosi Terhadap Keputusan Pembelian Kartu Simpati Pt. Selular Media Infotama(Studi Kasus Pada Counter Di Kecamatan Bukit Intan).Hasil penelitian menunjukkan bahwa kualitas pelayanan berpengaruh positif terhadap keputusan pembelian.

Menurut Isnaini et al (2015) mendefinisikan pelayanan adalah perilaku penjual kepada pembeli dengan memberikan kepuasan kepada konsumen atau pembeli, agar konsumen atau pembeli merasa dihargai dan mendapatkan barang atau jasa yang sesuai dengan keinginannya.

\section{Pengujian desain produk} terhadap keputusan pembelian Songket Silungkang Ande Darama di Gunung Pangilun Kota Padang.

Berdasarkan penelitian

diperoleh hasil desain produk memiliki nilai koefisien regresi positif dengan nilai $\mathrm{t}$ hitung sebesar 2,995 dengan nilai sig sebesar 0,004. Jika dibandingkan dengan ( $\mathrm{t}$ tabel, sig 0.05 , df $(75-3)=72)$. Maka dapat terlihat bahwa dengan nilai $t$ hitung 2,995, $>\mathrm{t}$ tabel 1,666, dan nilai sig 0,004 $<0.05$, maka dapat disimpulkan bahwa $\mathrm{Ha}$ diterima dan Ho ditolak artinya bahwa desaij produk berpengaruh dan signifikan terhadap keputusan pembelian konsumen.

Mendukung penelitian sebelumnya yang dilakukan oleh Saidani (2013) tentang Pengaruh Kualitas Produk Dan Desain Produk Terhadap Keputusan Pembelian Sepatu Olahraga Futsal Adidas Di Wilayah Jakarta Timur. Hasil penelitian menunjukkan bahwa desain produk berpengaruh positif terhadap keputusan pembelian.

Lalu penelitian ini juga dilakukan oleh Tengor (2016) tentang Pengaruh Merek, Desain Dan Kualitas Produk Terhadap Keputusan Pembelian Iphone Studi Kasus Pada Mahasiswa Stie Eben Haezar Manado. Hasil penelitian menunjukkan bahwa desain produk berpengaruh positif terhadap keputusan pembelian.

Selanjutnya penelitian yang dilakukan oleh Mahmud \& Alfianto (2014) tentang Pengaruh Desain Produk Dan Layanan Purna Jual Terhadap Keputusan Konsumen Membeli Sepeda Motor Yamaha Merek New V-Ixion Fi (Full Injection). Hasil penelitian menunjukkan bahwa desain produk 
berpengaruh positif terhadap keputusan pembelian.

Desain yang baik bagi perusahan merujuk pada kemudahan dalam pembuatan dan distribusi. Sedangkan bagi konsumen, desain yang baik adalah produk yang indah atau bagus untuk dilihat, mudah di buka, dipasang, digunakan, diperbaiki, dan dibuang (Kotler \& Keller, 2012).

\section{Pengujian lokasi terhadap keputusan pembelian Songket Silungkang Ande Darama di Gunung Pangilun Kota Padang.}

Berdasarkan penelitian diperoleh hasil lokasi memiliki nilai koefisien regresi positif dengan nilai $t$ hitung sebesar 5,847 dengan nilai sig sebesar 0,000. Jika dibandingkan dengan ( $\mathrm{t}$ tabel, sig 0.05, df $(75-3)=72)$. Maka dapat terlihat bahwa dengan nilai t hitung 5,847, > t tabel 1,666, dan nilai sig $0,000<0.05$, maka dapat disimpulkan bahwa $\mathrm{Ha}$ diterima dan $\mathrm{Ho}$ ditolak artinya bahwa lokasi berpengaruh dan signifikan terhadap keputusan pembelian konsumen.

Mendukung penelitian sebelumnya yang dilakukan oleh Avetoe \& Lamidi (2005) Tentang Pengaruh Harga, Kualitas Pelayanan Dan Lokasi Terhadap Keputusan Pembelian Konsumen. Hasil Penelitian Menunjukkan Bahwa Lokasi Berpengaruh Positif Terhadap Keputusan Pembelian.Selanjutnya penelitian yang dilakukan oleh Moningka \& Loindong (2016) Tentang Pengaruh Servicescape Dan Lokasi Terhadap Keputusan Pembelian Pada Manado Town Square I.

Menurut teori Suatu lokasi disebut strategis bila berada dipusat kota, kepadatan populasi, kemudahan mencapainya menyangkut kemudahan transportasi umum, kelancaran lalu lintas dan arahnya tidak membingungkan konsumen (Wibowo, 2014).

\section{SIMPULAN}

1. Kualitas pelayanan memiliki nilai koefisien regresi positif dengan nilai $t$ hitung sebesar 2,913 dengan nilai sig sebesar 0,005. Jika dibandingkan dengan (t tabel, sig 0.05, df $(75-3)=72$. Maka dapat terlihat bahwa dengan nilai $\mathrm{t}$ hitung $-2,913>\mathrm{t}$ tabel 1,666, dan nilai sig $0,005<0.05$, maka dapat disimpulkan bahwa Ha diterima dan Ho ditolak artinya bahwa kualitas pelayanan berpengaruh dan signifikan terhadap keputusan pembelian.

2. Desain produk memiliki nilai koefisien regresi positif dengan nilai $\mathrm{t}$ hitung sebesar 2,995 dengan nilai sig sebesar 0,004. Jika dibandingkan dengan $(\mathrm{t}$ tabel, sig 0.05, df (75-3) = 72). Maka dapat terlihat bahwa dengan nilai $\mathrm{t}$ hitung $2,995,>\mathrm{t}$ tabel 1,666, dan nilai sig 0,004 $<\quad 0.05$, maka dapat disimpulkan bahwa $\mathrm{Ha}$ diterima dan Ho ditolak artinya bahwa desaij produk berpengaruh dan signifikan terhadap keputusan pembelian konsumen.

3. Lokasi memiliki nilai koefisien regresi positif dengan nilai $\mathrm{t}$ hitung sebesar 5,847 dengan nilai sig sebesar 0,000. Jika dibandingkan dengan ( $\mathrm{t}$ tabel, sig 0.05, df $(75-3)=72)$. Maka dapat terlihat bahwa dengan nilai $\mathrm{t}$ hitung 5,847 , > $\mathrm{t}$ tabel 1,666 , dan nilai sig $0,000<$ 0.05 , maka dapat disimpulkan bahwa $\mathrm{Ha}$ diterima dan $\mathrm{Ho}$ ditolak artinya bahwa lokasi berpengaruh dan signifikan terhadap keputusan pembelian konsumen. 


\section{UCAPAN TERIMAKASIH}

Terimakasih penulis ucapkan kepada ketua STIE"KBP, Ketua program studi, dosen pembiming skripsi, dosen pembimbing akademik dan atau lembaga/institusi yang telah membantu dalam pelaksanaan penelitian dan penulisan karya tulis ilmiah serta lembaga lain yang berkontribusi terhadap penulis.

\section{DAFTAR PUSTAKA}

Avetoe, H., \& Lamidi. (2005). Pengaruh Harga, Kualitas Pelayanan Dan Lokasi Terhadap Keputusan Pembelian Konsumen Haja, 367-373.

Aziz, N. (2019). Pengaruh Kualitas Layanan Terhadap Kepuasan Nasabah SMS Banking Pada Bank Nagari Cabang Pembantu RSUP DR M Djamil Padang. https://doi.org/10.17605/OSF.IO/S3JV G

Budi Purbayu Santosa dan Ashari. (2005). Analisis Statistik dengan Microsoft Axcel \& SPSS. Yogyakarta, Andi Offset.

Dona, E. (2018). Kepuasan Publik Dilihat Dari Kualitas Pelayanan Dalam Pengurusan Perizinan (Kasus Badan Pelayanan Perizinan Terpadu, Pengadaan Barang Dan Jasa Kab. Dharmasraya).

Https://Doi.Org/10.31227/Osf.Io/8cjhg.

Fernandes, Y. D., \& Marlius, D. (2018). Peranan Customer Service Dalam Meningkatkan Pelayanan Kepada Nasabah Pada PT. Bank Pembangunan Daerah Sumatera Barat Cabang Utama Padang. https://doi.org/10.31227/osf.io/wrh3p

Fernos, J., \& Putra, Y. E. (2019). Analisa Pengaruh Kualitas Pelayanan Terhadap Kepuasan Nasabah Pada PT. Bank
Mega Syari'ah Padang. https://doi.org/10.31219/osf.io/y2 baf

Isnaini, Pratiwi, D., \& Aslinda. (2015). Analisis Pengaruh Kualitas Pelayanan, Kualitas Produk Dan Promosi Terhadap Keputusan Pembelian Kartu Simpati Pt. Selular Media Infotama, 4(November), 39-51.

Kotler, P., \& Keller, kevin lane. (2012). manajemen pemasaran. (A. Maulana \& W. Hardani, Eds.) (13th ed.). erlangga.

Mahmud, \& Alfianto, eko agus. (2014). Pengaruh Desain Produk Dan Layanan Purna Jual Terhadap Keputusan Konsumen Membeli Sepeda Motor Yamaha Merek New V-Ixion Fi (Full Injection), 1 .

Marlius, D. Putriani, I. (2019). Kepuasan Nasabah PT. Bank Rakyat Indonesia Unit Tapan Cabang Painan Dilihat dari Kualitas Layanan Customer Service. Jurnal Pundi. Volume 3. No. $2 . \quad$ Hal.111-122. https://doi.org/10.31575/jp.v3i2.1 51

Marlius, D. Ananda, F. (2019). Pengaruh Kualitas Pelayanan Website Akademik Terhadap Minat Kuliah di AKBP Padang. Jurnal Pundi, Vol. 03, No. 03. Hal. 191-204 https://doi.org/10.31575/jp.v3i3.1 90

Marlius, D. (2018). Loyalitas Nasabah Bank Nagari Syariah Cabang Bukittinggi Dilihat Dari Kualitas Pelayanan. Jurnal Pundi. Volume 
1. No. $3 . \quad$ Hal.12-22. https://doi.org/10.31575/jp.v1i3.60

Marlius, D. (2018). Pengaruh Dimensi Kualitas Pelayanan Website Akademik Terhadap Kepuasan Mahasiswa Pada STIE "KBP". Jurnal Ipteks Terapan. Volume 12. No. 2. Hal. 116-128. http://doi.org/10.22216/jit.2018.v12i2.6 33

Marlius, D. RD Putra. (2018). Strategi Pengembangan Sulam Bayang. Jurnal Benefita: Ekonomi Pembangunan Manajemen Bisnis Dan Akuntansi. Volume 3. No. 2. Hal. 204-218. http://doi.org/10.22216/jbe.v3i2.3494

Marlius, D. (2017). Keputusan Pembelian Berdasarkan Faktor Psikologis Dan Bauran Pemasaran Pada PT. Intercom Mobilindo Padang. Jurnal Pundi. Volume 1. No. 1. Hal. 57-66. https://doi.org/10.31575/jp.v1i1.9

Marlius, D. (2016). Pengaruh Bauran Pemasaran Jasa Terhadap Minat Nasabah Dalam Menabung Pada Bank Nagari Cabang Muaralabuh. https://doi.org/10.31227/osf.io/vdqgx

Moningka, ritskia friska cindy, \& Loindong, sjendry s. . (2016). Pengaruh servicescape dan lokasi terhadap keputusan pembelian pada manado town square i, 4(2), 778-788.

Mudrajad Kuncoro. (2001). Metode Kuantitatif Teori Dan Aplikasi Untuk Bisnis Dan Ekonomi Edisi Pertama. Yogyakarta, UPP AMP YPKN.

Putra, Y. E., \& Aziz, N. (2019). Pengaruh Kualitas Pelayanan Dan Kepuasan Pelanggan Terhadap Loyalitas Nasabah PT. Bank Rakyat Indonesia Cabang Padang. https://doi.org/10.31219/osf.io/hcsw2
Safitri, R. N., \& Marlius, D. (2017). Penerapan E-Banking Dalam Meningkatkan Jasa Dan Layanan Perbankan Di PT. Bank Rakyat Indonesia Cabang Padang. https://doi.org/10.31227/osf.io/gk v8t

Saidani, B. (2013). Pengaruh Kualitas Produk Dan Desain Produk Terhadap Keputusan Pembelian Sepatu Olahraga Futsal Adidas Di Wilayah Jakarta Timur, 4(2), 201-217.

Sriyanto, A., \& Kuncoro, aris wahyu. (2015). Pengaruh Kualitas Layanan, Ekuitas Merek dan Promosi Terhadap Keputusan Pembelian ProdukLionStar Di Mod e r n Marke t Jakarta, 4(2).

Sugiono, prof. D. (2015). statistik non parametris untuk penelitian. kota bandung, penerbit alfabeta.

Sugiyono. (2015a). statistik nonparametris untuk penelitian. (B. R. Setiadi, Ed.). Bandung: ALFABETA.

Sugiyono. (2015b). statistik nonparametris untuk penelitian. ( bayu rahmat Setiadi, Ed.). Bandung: ALFABETA.

Tengor, G. (2016). Pengaruh Merek, Desain Dan Kualitas Produk Terhadap Keputusan Pembelian Iphone Studi Kasus Pada Mahasiswa Stie Eben Haezarmanado, 16(4), 367-375.

Tiza, M. F., \& Susanti, F. (2019). Pengaruh Kualitas Pelayanan Terhadap Kepuasan Pelanggan, Studi kasus pada perusahaan JNE Cabang Padang. https://doi.org/10.31227/osf.io/hx 
$87 \mathrm{~m}$

Ulfa, M., \& Mayliza, R. (2019). Pengaruh Kualitas Pelayanan Dan Kepuasan Pelanggan Terhadap Loyalitas Pelanggan PDAM Kota Padang. https://doi.org/10.31219/osf.io/spmgv

Usman, H. (2003). Metodologi Penelitian Sosial. Jakarta, Bumi Aksara.

Wibowo, A. (2014). Pengaruh Kualitas Layanan, Harga Dan Lokasi Terhadap Keputusan Pembelian Di 'D'stupid Baker" Surabaya Ari, 3(12). 